\title{
Anatomical study of animal remains from Phoenician-Punic amphorae found in the Santa Giusta Pond, Sardinia (Italy)
}

\author{
Laura Portas, ${ }^{1}$ Vittorio Farina, ${ }^{1}$ Carla Del Vais, ${ }^{2}$ Marcella Carcupino, ${ }^{3}$ Ferdinando Gazza, ${ }^{4}$ \\ Ignazio Sanna, ${ }^{5}$ Marco Zedda ${ }^{1}$ \\ ${ }^{1}$ Department of Veterinary Medicine, University of Sassari, Sassari; ${ }^{2}$ Department of History, Cultural \\ Heritage and Territory, University of Cagliari, Cagliari; ${ }^{3}$ Department of Natural and Territory \\ Sciences, University of Sassari, Sassari; ${ }^{4}$ Department of Medico-Veterinary Sciences, University of \\ Parma, Parma; ${ }^{5}$ Cultural Heritage Authority for Cagliari and Oristano Provinces, Cagliari, Italy
}

\begin{abstract}
During the underwater excavations carried out in the Santa Giusta Pond, near Oristano, Sardinia, a significant amount of PhoenicianPunic materials was brought to light including amphorae (dating back to $7^{\text {th }}-2^{\text {nd }}$ century BC) and vegetal and animal remains. All of these archaeological finds may come from Othoca, an important PhoenicianPunic city on the eastern shore of the pond, geographically corresponding with the modern-day town of Santa Giusta. Animal materials consist of more than 3000 very well-preserved remains, belonging to sheep (Ovis aries), goat (Capra hircus) and cattle (Bos taurus). Bone analyses allowed reconstructing the slaughtering methods, as well as manipulation procedures carried out to preserve meat in order to be
\end{abstract}

Correspondence: Vittorio Farina, Department of Veterinary Medicine, University of Sassari, via Vienna 2, 07100 Sassari, Italy.

Tel. +39.079.229460.

E-mail: vfarina@uniss.it

Key words: Phoenician-Punic amphorae; Sheep; Goat; Cattle; Zooarchaeology.

Contributions: CDV and IS directed the archaeological excavations and gave the material its specific historical context; MZ and MC conceived and designed the research and interpreted the data; LP analyzed samples and drafted the article; FG and VF revised the text critically and approved the final version.

Conflict of interest: the authors declare no potential conflict of interest.

Funding: work supported by the Fondazione Banco di Sardegna.

Received for publication: 27 January 2015.

Revision received: 17 July 2015.

Accepted for publication: 20 November 2015.

(C) Copyright L. Portas et al., 2015

Licensee PAGEPress, Italy

Journal of Biological Research 2015; 88:5073

doi:10.4081/jbr.2015.5073

This article is distributed under the terms of the Creative Commons Attribution Noncommercial License (by-nc 3.0) which permits any noncommercial use, distribution, and reproduction in any medium, provided the original author(s) and source are credited. exported overseas. Although pig (Sus scrofa) played an important economical role in other Sardinian Phoenician-Punic settlements, in this archaeological context this species is absent, suggesting that the meat contained in the amphorae was probably destined to other areas of the Mediterranean basin, where people did not eat pork.

\section{Introduction}

It is well known that amphorae were the most used containers in ancient Mediterranean sea, because of their frequent use in sea trade. Their success and diffusion probably derive from the possibility to be hermetically plugged and piled in a small place, like a ship hold. They were widely used by Phoenicians, Punics and Romans and produced locally with clay. Amphorae could be recycled after their commercial use as funerary urns or, when broken, as building materials.

Archaeologists evaluate the studies of amphorae contents as very important to better understand the economy, culture, social features and sea trade of ancient societies. When biological remains, such as seeds, wood, coal, animal bones and teeth, are present inside of amphorae, important information about agriculture, gathering, fishing, hunting and breeding allows reconstructing the relationship among humans, animals and plants in the past. Indeed, zooarchaeological analyses allow understanding which animals were bred, fished or hunted for commercial shipping.

The underwater excavations carried out in 2005-2007 in the Santa Giusta Pond allowed to dig out a significant number of PhoenicianPunic materials, very well preserved by anoxic silt. All of these archaeological finds may come from Othoca, an important Phoenician-Punic city on the eastern shore of the pond with a strategical position, and geographically corresponding to the present-day town of Santa Giusta.

During the excavations, an interesting deposit was discovered. Abundant ceramic materials were recovered, dating back to $7^{\text {th }}-2^{\text {nd }}$ century BC, including a significant number of amphorae (Figure 1) containing vegetal and animal remains. Probably Othoca was a flourishing trade centre, where methods of food preservation were practiced. ${ }^{1}$

\section{Materials and Methods}

A rather high number of amphorae were broken and a lot of bones were spread on the pond bed all around. Consequently, the exact relationship between the individual bone elements and the amphora in which they were contained was unfortunately not easy to be deduced. 
All faunal material was catalogued and photographed at the Zooarchaeological Laboratory, Department of Veterinary Medicine, University of Sassari. The current techniques of zooarchaeology ${ }^{2,3}$ were applied according to the following steps: separation into categories (skull, vertebrae, ribs, limb bones), exact identification of the remains, recognition of species, estimation of the age of death and analysis of possible marks.

The osteological collection belonging to the Zooarchaeological Laboratory has been taken as reference for comparative anatomy. This collection includes thousands of isolated bones and teeth, and complete skeletons of Sardinian domestic and wild animal species. The bones from Ovis aries and Capra hircus were joined into the taxonomic category Ovis vel Capra. The observed percentages of entire long bones, mandibulae, vertebrae, ribs, scapulae and coxae were compared to the expected percentages calculated on account of its natural frequency referred to vertebrae in a normal complete skeleton. Vertebrae were chosen as a reference since they are numerous in the normal skeleton and possible errors due to taphonomical alterations in number are reduced.

The estimation of the age of death was based on the fusion of ossification centers, in agreement with Barone. ${ }^{4}$

The remains showing marks on the surface were separated and underwent stereomicroscopic analysis to distinguish their origin. Indeed, they may be human marks mostly derived from slaughtering, meat preparation and cooking (Figure 2), or non-human ones, like bites of carnivores and ruts of rodents.

\section{Results}

The animal remains were found within the amphorae or close to them and consist of 3088 remains, about $15 \mathrm{~kg}$ total weight. The remains are very well preserved with a little degree of fragmentation. Apart from 513 undetermined remains, the majority of them (2075) belong to the domestic sheep (Ovis aries), goat (Capra hircus), and cattle (Bos taurus). In addition, remains of other species were found: small birds (145) and fish (355) among them mullets (Mugil cephalus). These non-mammalian remains are currently being studied to evaluate their antiquity and provenience. For this reason, no results are shown here. The minimum number of individuals (MNI) is high and precisely 146, that is 108 Ovis vel Capra and 38 from cattle. In order to evaluate

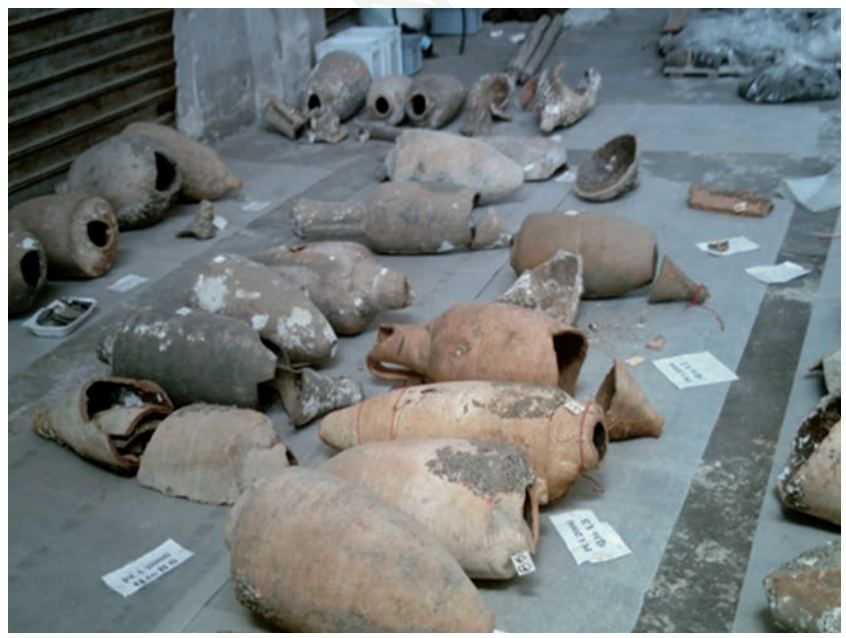

Figure 1. Some of the Phoenician Punic amphorae brought to light from the Santa Giusta Pond. the possible presence of favorite anatomical parts, 8 body regions were considered: skull (including teeth and horns), thorax-rachis-pelvis, shoulder, arm, forearm, thigh, leg and hand-foot (Figure 3).

The remains belonging to Ovis vel Capra are 1319. In details, 209 bones

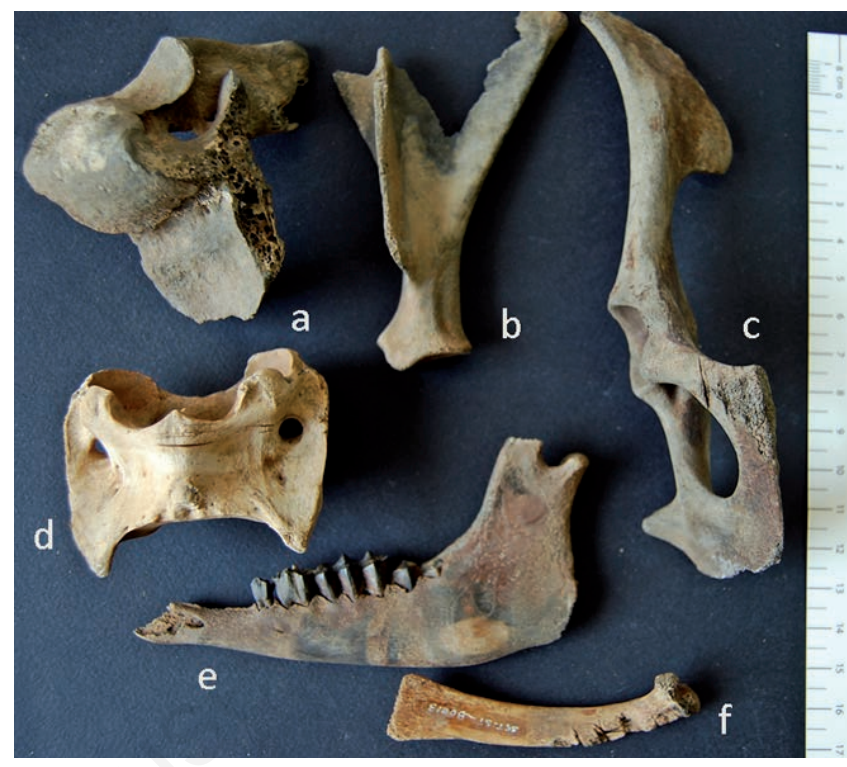

Figure 2. Fragment of occipital bone (a), fragment of left scapula (b), right coxa (c), atlas (d), left mandibula (e), rib (f). a) cattle; bf) Ovis vel Capra. Note the presence of evident burning marks on a), b), e) and cutting marks on c), d), f).

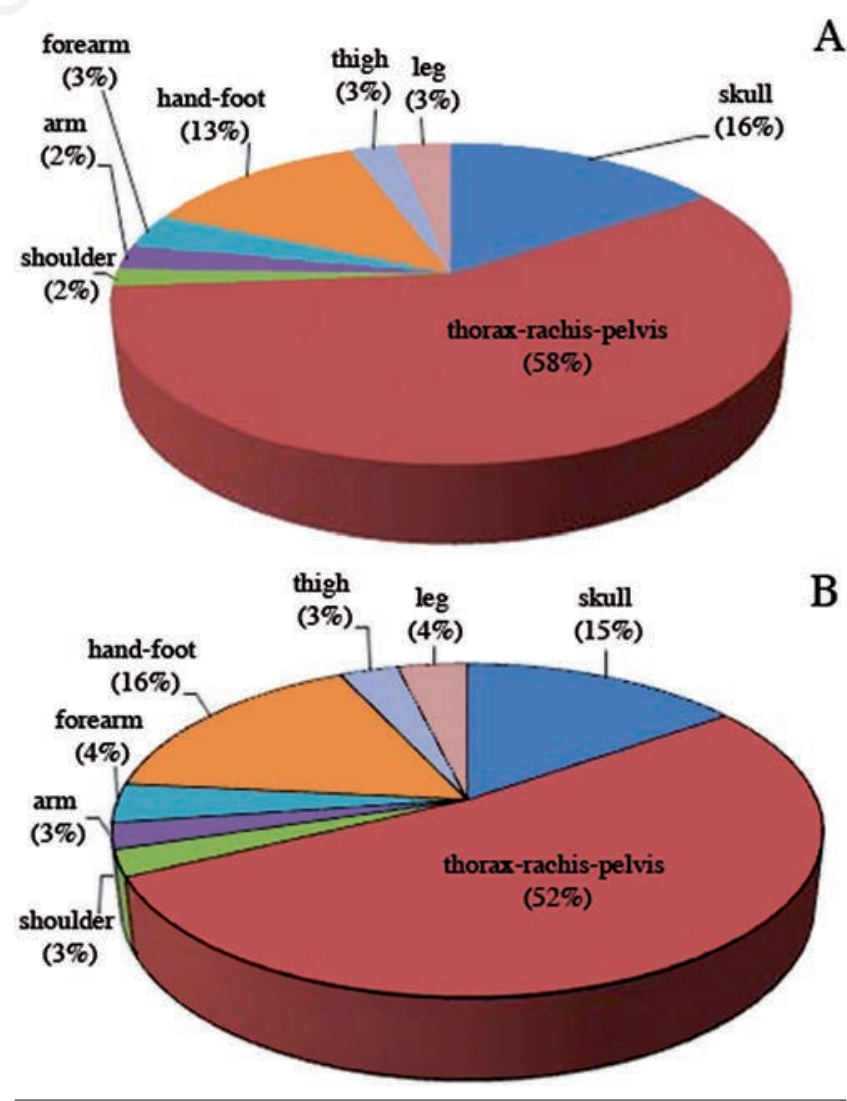

Figure 3. Percentual distribution of the bone remains in different anatomical regions of Ovis vel Capra (A) and Bos Taurus (B). 
belong to skull, 764 to thorax-rachis-pelvis, 22 to shoulder, 33 to arm, 46 to forearm, 169 to hand-foot, 33 to thigh and 43 to leg (Figure 3). Cattle remains (Figure 3 ) are 158 and assigned to skull (24 bones and teeth), thorax-rachis-pelvis (83), shoulder (4), arm (4), forearm (6), hand-foot (26), thigh (5) and leg (6). Table 1 summarizes the results obtained on entire long bones, mandibulae, vertebrae, ribs, scapulae and coxae.

A significant number of remains belongs to young animals. This was observed both in cattle and Ovis vel Capra. Numerous remains show cutting and burning marks, so permitting to reconstruct slaughtering methods and food preparation processes, as well as cooking and preservation procedures.

\section{Discussion}

All faunal materials were very well preserved. Indeed, all remains stayed underwater for 23-27 centuries. The remains were covered by a layer of silt and mud, which determined an anoxic microenvironment, ideal condition for preservation. Probably due to these circumstances, some bone remains had greenish spots, as previously observed in faunal remains coming from Phoenician-Punic amphorae found in the seabed of Nora, south-western Sardinia. ${ }^{5}$ As to the possibility to introduce the body portions into the amphorae, some reflections may be made. The bones are for the most part intact, as the only few fragmented bones are long bones especially belonging to cattle. They might have been intentionally cut together with the surrounding muscle masses, in order to make them small enough to fit into the amphorae. Indeed, it is to be noted that their opening was about $15 \mathrm{~cm}$ in diameter, as is well-documented for Phoenician-Punic amphorae. ${ }^{6}$

In many cases, animals were slaughtered at a young age, so that tender and juicy meat suitable for trading could be obtained. The cut marks suggest a slaughtering interpretation: the animal body was divided in large portions. The limbs were disarticulated from the rest of the body and sectioned at the main joints, such as shoulder, elbow, hip, knee and stifle joints. Even the vertebral column was cut to obtain segments of 4-7 vertebrae each. It could be hypothesized that whole long bones could be inserted into the amphorae vertically to facilitate the introduction of complete limbs belonging to lambs and kids.

Moreover, it is to be noted that all the body parts were present, includ- ing pieces devoid of muscles and consequently with poor nutritional value. This is the case, for example, of hands and feet, rich in tendons, ligaments and cartilages. It is to be noted that culinary recipes can be found in the Mediterranean area till today that are not based on meat, but on fibrous tissues, and are still widespread and appreciated. ${ }^{7}$ In Ovis vel Capra the actual percentages of limb bones are higher than those of natural frequency referred to vertebrae, suggesting a possible preference in the choice of some anatomical parts. It could be hypothesized that limbs belonging to Ovis vel Capra were preferred because of their small size allowing their introduction within the amphorae. Such hypothesis could account for the lower number of bovine limb bones.

Some remains show evidence of burns caused by cooking and smoking of the meat. Burning marks can be detected everywhere on the bone surface, but especially where bones where broken or not covered by soft tissues. These cooking procedures were probably carried out in order to avoid degradation of food during the sea trade, which could take some days. The finding of many vegetal remains, such as grape seeds (Vitis vinifera), pine cones (Pinus halepensis and Pinus pinea), almonds (Prunus dulcis) and others suggests that they were usually added to meat for preservation and spicing. ${ }^{8}$

The bones belong to sheep, goat and cattle, the most common domesticated mammals in the Mediterranean basin. It can be of some interest the absence of remains from pig (Sus scrofa), whereas that species played an important economical role in other Phoenician-Punic settlements in Sardinia, such as Tharros, ${ }^{9}$ Nuraghe Lugherras, Olbia, Sant'Antioco, Nuraghe Sirai, ${ }^{10}$ and Monte Sirai. ${ }^{11}$ Our findings on the lack of pig remains agree with what found by $\mathrm{Fonzo}^{12}$ in Punic amphorae from Santa Gilla pond, near the city of Cagliari, where pig remains were not found. Even if the topic is still matter of debate, it is possible that Phoenicians did not usually eat pork, ${ }^{13}$ even though that habit may have been influenced by the local customs of the colonized areas. ${ }^{14}$ As to Sardinian settlements where pork was abundantly eaten by Nuragic people, ${ }^{15-17}$ it is possible that Phoenicians adjusted their food traditions to the local livestock farming and changed their culinary taste, ${ }^{14}$ as is testified by the high number of pig remains found in the Phoenician Punic settlements mentioned above. Due to the absence of this species, we are inclined to believe that the amphorae found in Santa Giusta Pond were destined to be exported to areas where pork was not appreciated. That cannot be more than a hypothesis, due to the difficulties in decoding the relationship between locals, outsiders, and postcolonial contexts. The amphorae were produced in Phoenician-

Table 1. Results obtained on entire long bones, mandibulae, vertebrae, ribs, scapulae and coxae.

\begin{tabular}{|c|c|c|c|c|c|c|c|c|c|c|c|c|}
\hline \multirow[t]{2}{*}{ Bones } & \multicolumn{6}{|c|}{ Ovis vel Capra } & \multicolumn{6}{|c|}{ Bos taurus } \\
\hline & $\begin{array}{l}\text { Remains } \\
\text { (n) }\end{array}$ & $\begin{array}{l}\text { Exp } \\
(\%)\end{array}$ & $\begin{array}{l}\text { Obs } \\
(\%)\end{array}$ & $\begin{array}{l}\text { Burning } \\
\text { marks (n) }\end{array}$ & $\begin{array}{l}\text { Cutting } \\
\text { marks (n) }\end{array}$ & $\begin{array}{l}\text { Young } \\
\text { bones (n) }\end{array}$ & $\begin{array}{l}\text { Remains } \\
\text { (n) }\end{array}$ & $\begin{array}{l}\text { Exp } \\
(\%)\end{array}$ & $\begin{array}{l}\text { Obs } \\
(\%)\end{array}$ & $\begin{array}{l}\text { Burning } \\
\text { marks (n) }\end{array}$ & $\begin{array}{l}\text { Cutting } \\
\text { marks (n) }\end{array}$ & $\begin{array}{c}\text { Young } \\
\text { bones (n) }\end{array}$ \\
\hline Mandibula & 18 & 5.7 & 7.7 & 4 & 1 & 2 & 3 & 5.7 & 1.3 & - & - & 1 \\
\hline Vertebrae & 442 & - & - & 15 & 3 & 37 & 38 & - & - & - & 3 & 14 \\
\hline Ribs & 263 & - & - & 36 & 49 & 28 & 17 & - & - & - & 5 & - \\
\hline Scapula & 22 & 5.7 & 9.4 & - & - & 7 & 4 & 5.7 & 1.8 & - & 1 & - \\
\hline Humerus & 33 & 5.7 & 14 & 2 & 2 & 18 & 4 & 5.7 & 1.8 & - & - & 3 \\
\hline Radius & 34 & 5.7 & 14 & 1 & - & 27 & 4 & 5.7 & 1.8 & - & - & 2 \\
\hline Ulna & 12 & 5.7 & 5.1 & 4 & - & 4 & 2 & 5.7 & 0.9 & - & - & - \\
\hline Coxae & 31 & - & - & 4 & - & 3 & 4 & - & - & - & - & 1 \\
\hline Femur & 33 & 5.7 & 14 & 5 & 1 & 14 & 5 & 5.7 & 2.1 & - & - & 4 \\
\hline Tibia & 34 & 5.7 & 14.5 & - & - & 27 & 4 & 5.7 & 1.8 & - & - & 1 \\
\hline Metapodials & 56 & 11.4 & 24 & 3 & 1 & 33 & 3 & 11.4 & 1.3 & - & - & 3 \\
\hline
\end{tabular}

Exp, expected percentages on account of the natural frequency referred to vertebrae; Obs, observed percentages; Young bones, bones with still incomplete ossification process. 
Punic Sardinia, as recent archaeometrical analysis set up on ceramic mixtures coming from Olbia, ${ }^{18}$ as well as investigations carried out in Sulki ${ }^{19}$ and Nora ${ }^{5}$ showed. So, it does not seem that the amphorae and their content were imported.

Chemical analyses carried out on numerous amphorae from Phoenician and Punic settlements of southwestern Sardinia demonstrated the presence of organic compounds coming from animal remains, such as animal fat and beeswax used for waterproofing the inner surface of the amphorae. ${ }^{20}$ Another study highlighted the presence of fish remains belonging to golden grey mullet (Mugil auratus) and curled picarel (Spicada alcedo) found into two Punic amphorae from Olbia, ${ }^{21-23}$ suggesting a multifunctional role of these containers for food sea trade.

\section{Conclusions}

This study is aimed at improving the knowledge of the economical organization, production and trade during the Phoenician-Punic colonization in Sardinia. The remains found in Santa Giusta Pond represent an interesting case in archaeological discoveries. Indeed, the peculiar underwater environment, in the absence of external agents, led to a high level of preservation and protected the remains from degradation. Such ideal conditions allowed a representation of the use of amphorae, the animal food that Phoenicians and Punics appreciated and commercialized, and the techniques of meat preparation and preservation. To sum up, the present investigation described the faunal content of ancient amphorae, thus shedding light on the dietary and economical customs and trade in Punic Sardinia.

\section{References}

1. Del Vais C, Sanna I. Ricerche su contesti sommersi di età feniciopunica nella laguna di santa Giusta (OR) (campagne 2005-2007). Studi Sardi 2009;34:123-49.

2. Chaix L, Méniel P. Elements d'archéozoologie. Paris, France: Errance; 1996.

3. Reitz EJ, Wing ES. Zooarcheology. Cambridge, UK: Cambridge University Press; 2008.

4. Barone R. Anatomie comparée de mammifères domestiques. Vol. 1 Osteologie. Paris, France: Vigot Frères; 1980.

5. Poplin F. Les ossements de 1984 étudiés au printemps 2013. In: Bossetto J, ed. Nora e il mare. I. Le ricerche di Michel Cassien (19781984). Padua, Italy: Padova University Press; 2014. pp 551-66.

6. Bartoloni P. Le anfore fenicie e puniche della Sardegna. Rome, Italy: Università degli Studi di Roma Tor Vergata; 1988.

7. Meldolesi A. Mille ricette della cucina italiana. Milan, Italy: Rizzoli; 2010.
8. Sabato D, Ucchesu M, Peña-Chocarro L, et al. Resti vegetali da contesti subacquei di età fenicia e punica della laguna di Santa Giusta (OR). In: Proc. 8th Int. Congr. Phoenicians and Punic Studies, Carbonia - Sant'Antioco, 21-26 October, 2013.

9. Farello P. Reperti faunistici punici da Tharros (OR), Sardegna. In: Proc. 2nd National Congress of Archeozoology (Asti, 1997). Forlì, Italy: Abaco Edizioni; 2000. pp 293-300.

10. Carenti G. Nuraghe Sirai: studio archeozoologico. Rivista di Studi Fenici 2005;33:217-24.

11. Carenti G, Wilkens B. La colonizzazione fenicia e punica e il suo influsso sulla fauna sarda. Sardinia Corsica et Baleares Antiquae 2006;4:173-86.

12. Fonzo 0. Preservation and transport of meat in Cagliari (Sardinia) in Punic Age ( $5^{\text {th }}-4^{\text {th }}$ century B.C.). In: Proc. 3rd Nat. Congr. on Archeozoology (Siracusa, 2000). Rome, Italy: Istituto Poligrafico e Zecca dello Stato; 2005. pp. 365-9.

13. Müller FL. Herodian. Geschichte des Kaisertums nach Marc Aurel: Griechisch und Deutsch. Stuttgart: Franz Steiner; 1996.

14. Campanella L, Zamora JA. Il maiale presso le comunità fenicie e puniche di Sardegna: leggi, tabù e consuetudini alimentari tra culture a contatto. Rome, Italy: Ministero per i Beni e le Attività Culturali; 2008. Available from: http://www.bollettinodiarcheologiaonline.beniculturali.it/documenti/generale/6_CAMPANELLA_ZA MORA.pdf

15. Wilkens B. La fauna sarda durante l'Olocene: le conoscenze attuali. Sardinia, Corsica et Baleares antiquae 2003;1:181-97.

16. Albarella U, Manconi F, Rowley-Conwy P, Vigne JD. Pigs of Corsica and Sardinia: a biometrical re-evaluation of their status and history. In: Tecchiati U, Sala B, eds. Archaeozoological studies in honour of Alfredo Riedel. Bolzano, Italy: Ufficio Beni Archeologici; 2006. pp 285-302.

17. Wilkens B. Archeozoologia. Il Mediterraneo, la storia, la Sardegna. Sassari: Edes; 2012.

18. Amadori ML, Del Vais C, Raffaelli G. Indagini archeometriche sulla ceramica punica a vernice nera dell'ex Mercato di Olbia. In: Gualtieri S, Fabbri B, Bandini G, eds. Proc. 10th Day of Archeometry of Ceramics, Rome, Apr 5-7, 2006. Bari, Italy: Edipuglia; 2009. pp 111-20.

19. Botto M. Da Sulky a Huelva: considerazioni sui commerci fenici nel Mediterraneo antico. Annali di Archeologia e Storia Antica 2006;11-12:9-27.

20. Bordignon F, Botto M, Positano M, Trojsi G. Identificazione e studio di residui organici su campioni di anfore fenicie e puniche provenienti dalla Sardegna sud-occidentale. Mediterranea 2005;2:189-217.

21. Cavaliere P. Anfore puniche utilizzate come contenitori di pesce, un esempio olbiese. Antiquité T 2000;112:67-72.

22. Delussu F, Wilkens B. Le conserve di pesce. Alcuni dati da contesti italiani. Antiquité T 2000;112:53-65.

23. Wilkens B. I resti ittici dal magazzino del IV-III sec. a.C. di Olbia. Rivista di Studi Punici 2000;1:81-8. 